\title{
AKULTURASI DAN KEARIFAN LOKAL DALAM TRADISI BAAYUN MAULID PADA MASYARAKAT BANJAR
}

\author{
Zulfa Jamalie \\ Fakultas Dakwah dan Komunikasi IAIN Antasari \\ e-mail: zuljamalie@gmail.com
}

\begin{abstract}
This research examines the acculturation and transformation of traditional values of Banjarese Baayun Maulud. It used religious anthropology approach as an effort to understand the deepest meaning of the research object. The result shows that this tradition was historically started from swinging child ceremony of Dayakese Tribe in Kalimantan, in order to give blessing, give name, pray for safety, and to thank for the child birth. A long with the incoming and development of Islam in this region, the ceremony which was inherited by the ancestors experienced changes. The Islamic preachers have changed and acculturated this ceremony so it is full of Islamic values. The ceremony once called swinging child ceremony, then after the acculturation it became Baayun Maulud. The venue is centralized at the mosque and is combined with the celebration of Muhammad's birthday. The children are swung with qur'an recitation, rhyme quatrains of maulud, and prayers. The local wisdoms and the religious thoughts has been unified in harmony in the tradition, which becomes the sign of gratitude expressions for the child birth, as well as for celebrating and honoring the birth of the Greatest Prophet Muhammad SAW.
\end{abstract}

Penelitian ini mengkaji akulturasi dan transformasi nilai dalam tradisi Baayun Maulid masyarakat Banjar. Penelitian ini menggunakan pendekatan antropologis keagamaan sebagai upaya memahami makna mendalam dari objek penelitian. Hasil penelitian menunjukkan bahwa sejarah munculnya tradisi ini bermula dari upacara maayun anak masyarakat Dayak Kalimantan untuk memberikan keberkahan, memberi nama, menyampaikan doa keselamatan, dan tanda syukur atas kelahiran anak. Seiring dengan masuk dan berkembangnya Islam di 
kawasan ini, upacara yang diwariskan oleh nenek moyang ini pun mengalami perubahan. Ulama penyebar Islam telah merubah dan mengakulturasi upacara ini menjadi sarat dengan nilai-nilai keislaman. Apabila semula upacara ini dinamakan Baayun Anak, maka sesudah diakulturasi berubah menjadi Baayun Maulid. Tempat pelaksanaan dipusatkan di masjid dan disandingkan dengan peringatan maulid Nabi. Anak diayun dan dibacakan al Quran, syairsyair maulid, serta doa. Tradisi lokal dan ajaran agama telah bersatu secara harmonis dalam kegiatan Baayun Maulid, yang menjadi penanda kesyukuran atas kelahiran anak sekaligus peringatan dan penghormatan atas kelahiran Nabi Muhammad SAW.

Keywords: Baayun Maulid, acculturation, culture, tradition, local wisdom

\section{Pendahuluan}

Agama dan budaya adalah dua hal yang saling berinteraksi dan saling mempengaruhi. Pertama, agama mempengaruhi kebudayaan dalam pembentukannya. Nilainya adalah agama, tetapi simbolnya adalah kebudayaan. Kedua, budaya dapat mempengaruhi simbol agama. Ketiga, kebudayaan dapat menggantikan sistem nilai dan simbol agama (Kuntowijoyo, 2001: 196).

Agama dan kebudayaan mempunyai dua persamaan, yaitu keduanya adalah sistem nilai dan sistem simbol dan keduanya mudah sekali terancam setiap kali ada perubahan. Agama dalam perspektif ilmu-ilmu sosial adalah sebuah sistem nilai yang memuat sejumlah konsepsi mengenai konstruksi realitas, yang berperan besar dalam menjelaskan struktur tata normatif dan tata sosial serta memahamkan dan menafsirkan dunia sekitar. Sementara budaya merupakan ekspresi cipta, karya, dan karsa manusia yang berisi nilai-nilai dan pesan-pesan religiusitas, wawasan filosofis dan kearifan lokal (local wisdom).

Agama maupun kebudayaan, pada prinsipnya sama-sama memberikan wawasan dan cara pandang dalam menyikapi kehidupan agar sesuai dengan kehendak Tuhan dan kemanusiaannya. Misalnya, dalam menyambut anak yang baru lahir, Islam memberikan wawasan untuk melaksanakan tasmiyah (pemberian nama) dan akikah (penyembelihan hewan) bagi anak tersebut. Sementara kebudayaan lokal masyarakat Banjar yang dikemas dalam bentuk Tradisi Maayun atau Baayun Anak yang kemudian disandingkan dengan peringatan kelahiran Nabi Muhammad SAW atau Maulud Rasul (sehingga kemudian berubah menjadi Baayun Maulid) memberikan wawasan dan cara pandang lain, tetapi memiliki tujuan yang sama, yaitu mendoakan agar anak yang diayun menjadi anak yang berbakti, anak yang saleh, dan anak yang mengikuti Nabi Muhammad SAW sebagai uswah hasanah dalam kehidupannya kelak. 
Menurut catatan sejarah, Baayun Anak semula merupakan upacara peninggalan nenek moyang orang Banjar ketika masih beragama Kaharingan. Tradisi ini semula hanya ada di Kabupaten Tapin (khususnya di Desa Banua Halat Kecamatan Tapin Utara) kemudian berkembang dan dilaksanakan di berbagai daerah di Kalimantan Selatan (Usman, 2000: 4).

Sebelum Islam masuk, orang-orang Dayak Kaharingan yang berdiam di Kampung Banua Halat biasanya melaksanakan upacara aruh ganal yang diikuti dengan prosesi Baayun Anak. Upacara ini dilaksanakan secara meriah dan besar-besaran ketika sawah menghasilkan banyak padi. Aruh ganal yang diisi oleh pembacaan mantra atau mamangan dari para balian dan dilaksanakan di balai. Setelah Islam masuk dan berkembang serta berkat perjuangan dakwah para ulama, akhirnya upacara tersebut dapat diislamisasikan. Akulturasi terhadap tradisi ini terjadi secara damai dan harmonis serta menjadi substansi yang berbeda dengan sebelumnya, yaitu menjadi tradisi baru yang bernafaskan Islam (Usman, 2000: 5).

Nilai utama yang hendak ditanamkan oleh para ulama dalam upacara Baayun Anak dan mengisinya dengan pembacaan syair-syair maulid di Desa Banua Halat tersebut tidak lain sebagai bagian dari strategi dakwah kultural, yakni bentuk dakwah yang dilakukan melalui pendekatan budaya. Kehadiran tradisi Baayun Maulid pada akhirnya juga dijadikan sebagai salah satu sarana atau media untuk menyampaikan dakwah ke tengah-tengah masyarakat. Kegiatan yang dikemas secara khusus ini menjadi peristiwa penting bagi masyarakat Desa Banua Halat dan sekitarnya (bahkan diikuti pula oleh berbagai kelompok masyarakat Banjar lainnya).

Berdasarkan kenyataan di atas, Baayun Maulid atau Baayun Anak adalah proses budaya yang menjadi salah satu simbol kearifan dakwah ulama Banjar dalam mendialogkan makna hakiki ajaran agama dengan budaya masyarakat Banjar. Maulid adalah simbol agama dan menjadi salah satu manifestasi untuk menanamkan, memupuk, dan menambah kecintaan sekaligus pembumian sosok manusia pilihan, manusia teladan, Nabi pembawa Islam. Sedangkan Baayun Anak penerjemahan dari manifestasi tersebut, karena dalam Baayun Anak terangkum deskripsi biografi Nabi Muhammad SAW sekaligus doa, upaya, dan harapan untuk meneladaninya.

Tradisi Baayun Anak atau Baayun Maulid yang setiap tahun digelar oleh masyarakat Banjar, yakni setiap tanggal 12 Rabiul Awal, memiliki kemiripan sejarah dengan berbagai budaya Banjar lainnya yang telah berhasil diislamisasikan (diakulturasi atau ditransformasi). Baayun Maulid sarat dengan sejarah, 
muatan nilai, filosofis, akulturasi, dan prosesi budaya yang berharga untuk dikaji secara komprehensif, sehingga nilai-nilai filosofis yang terkandung di dalamnya penting untuk disosialisasi dan terinternalisasi dengan baik dalam kehidupan masyarakat. Penelitian ini diharapkan pula akan menghasilkan pemahaman-pemahaman yang terhadap proses perkembangan Islam yang telah berakulturasi dan berdialektika dengan budaya dan kepercayaan masyarakat lokal yang telah hadir sebelumnya, sebagaimana yang tampak dalam pelaksanaan tradisi Baayun Anak dalam masyarakat Banjar.

\section{Konsep Akulturasi dan Transformasi}

Secara bahasa akulturasi berarti percampuran dua kebudayaan atau lebih yang saling bertemu dan saling mempengaruhi. Dilihat dari sudut antropologi akulturasi adalah proses masuknya pengaruh kebudayaan asing dalam suatu masyarakat yang sebagian menyerap secara selektif sedikit atau banyak unsur kebudayaan asing itu dan sebagian berusaha menolak pengaruh itu. Sedangkan dari sudut linguistik akulturasi adalah proses atau hasil pertemuan kebudayaan atau bahasa di antara anggota dua masyarakat bahasa yang ditandai oleh peminjaman bahasa atau bilingualism (Tim Penyusun, 2008: 31-32).

Akulturasi adalah perpaduan kebudayaan yang terjadi bila suatu kelompok manusia dengan suatu kebudayaan tertentu dihadapkan dengan unsur-unsur dari suatu kebudayaan asing yang berbeda, sehingga unsurunsur kebudayaan asing tersebut lambat laun diterima dan diolah dalam kebudayaan sendiri tanpa menghilangkan kepribadian budaya sendiri (Koentjaraningrat, 2002: 248).

Pengertian lain akulturasi merujuk pada tiga hal penting. Pertama, akulturasi menunjuk kepada suatu jenis perubahan budaya yang terjadi apabila dua sistem budaya bertemu; kedua, akulturasi menunjuk kepada suatu proses perubahan yang dibedakan dari proses difusi, inovasi, invensi maupun penemuan; dan ketiga, akulturasi dipahami sebagai suatu konsep yang dapat digunakan sebagai kata sifat untuk menunjuk suatu kondisi, misalnya kondisi kelompok budaya yang satu lebih terakulturasi dari budaya lain (Hadi, 2006: 35).

Apabila dilihat dari definisi di atas tentang akulturasi maka dapat disimpulkan bahwa akulturasi adalah proses penggabungan antara dua kebudayaan atau lebih untuk mencari jalan tengah di mana pada kebudayaan baru yang terbentuk tersebut masih dapat ditemukan karakter asli dari unsur-unsur kebudayaan penyusunnya. 
Istilah lain yang memiliki kemiripan dengan kata akulturasi dan terkadang juga dipakai untuk menggambarkan hubungan antara Islam dan budaya adalah dialektika dan transformasi. Dialektika berasal dari bahasa Yunani pada mulanya menunjuk pada debat utama menolak argumentasi lawan (Bagus, 1996: 161). Menurut Kamus Besar Bahasa Indonesia, dialektika bermakna sebagai hal berbahasa dan bernalar dengan menggunakan dialog sebagai cara untuk menyelidiki suatu masalah. Ajaran Hegel yang menyatakan bahwa segala sesuatu yang terdapat di alam semesta itu terjadi dari hasil pertentangan antara dua hal dan yang menimbulkan hal lain lagi (Tim Penyusun, 1999: 231). Sedangkan istilah transformasi bermakna perubahan rupa (bentuk, sifat, fungsi dan sebagainya) dengan cara menambah, mengurangi, atau menata kembali unsur-unsur dari yang ditransformasikan tersebut (Tim Penyusun, 2008: 1728).

Islam datang untuk mengatur dan membimbing masyarakat menuju kepada kehidupan yang baik dan seimbang. Islam adalah agama yang berkarakteristik universal dengan pandangan hidup mengenai persamaan, keadilan, takaful, kebebasan dan kehormatan serta memiliki konsep yang humanistik (kemanusiaan) sebagai nilai inti (core value) dari seluruh ajaran Islam. Islam mempunyai karakter dinamis, elastis dan akomodatif dengan budaya lokal selama tidak bertentangan dengan prinsip-prinsip Islam itu sendiri. Budaya Sebagai Basis Dakwah

Islam yang hadir di Indonesia tidak bisa dilepaskan dengan tradisi atau budaya Indonesia. Agama dan budaya adalah dua hal yang saling berinteraksi dan saling mempengaruhi (Kuntowijoyo, 2001: 196). Agama dalam perspektif ilmu-ilmu sosial adalah sebuah sistem nilai yang memuat sejumlah konsepsi mengenai konstruksi realitas. Agama berperan besar dalam menjelaskan struktur tata normatif dan tata sosial serta memahamkan dan menafsirkan dunia sekitar. Sementara, tradisi merupakan ekspresi cipta, karya, dan karsa manusia (dalam masyarakat tertentu) yang berisi nilai-nilai dan pesan-pesan religiusitas, wawasan filosofis dan kearifan lokal (local wisdom, local genius). Local wisdom dapat dipahami sebagai gagasan-gagasan setempat (lokal) yang bersifat bijaksana, penuh kearifan, bernilai baik yang tertanam dan diikuti oleh anggota masyarakatnya dan terwariskan dari generasi ke generasi. Sedangkan local genius adalah cultural identity, identitas dan kepribadian budaya bangsa yang menyebabkan bangsa tersebut mampu menyerap dan mengolah kebudayaan asing sesuai watak dan kemampuan sendiri (Sartini, 2004: 111).

Kebudayaan dan agama masing-masing mempunyai simbol-simbol dan 
nilai tersendiri. Agama adalah simbol yang melambangkan nilai ketaatan kepada Tuhan. Kebudayaan juga mengandung nilai dan simbol supaya manusia bisa hidup di dalamnya. Agama memerlukan sistem simbol, dengan kata lain agama memerlukan kebudayaan agama, tetapi keduanya perlu dibedakan. Agama adalah sesuatu yang final, universal, abadi (parennial) dan tidak mengenal perubahan (absolut). Sedangkan kebudayaan bersifat partikular, relatif dan temporer. Agama tanpa kebudayaan memang dapat berkembang sebagai agama pribadi, tetapi tanpa kebudayaan agama sebagai kolektivitas tidak akan mendapat tempat (Kuntowijoyo, 2001: 196). Dengan demikian, dialektika antara agama dan kebudayaan merupakan sebuah keniscayaan. Agama memberikan warna (spirit) pada kebudayaan, sedangkan kebudayaan memberi kekayaan terhadap pelaksanaan ajaran agama. Hal inilah yang terjadi dalam dinamika keislaman di Indonesia (Paisun, 2010: 234).

Islam dalam aplikasinya ternyata memiliki ragam-variasi sesuai dengan masa dan tempat. Maksudnya, manifestasi keberagamaan mengambil tempat dalam pelataran budaya yang beragama. Manusia adalah makhluk berbudaya yang tidak luput dari pengaruh jaring-jaring kebudayaan dalam perilakunya (Hidayat, 1992: 35). Ini bermakna bahwa dakwah Islam dalam sejarahnya telah disampaikan melalui proses interaksi yang melibatkan unsur budaya sebagai media sekaligus objeknya. Berdasarkan kenyataan demikian, maka dapat disimpulkan bahwa wajah Islam di Indonesia merupakan hasil dialog dan dialektika antara Islam dan budaya lokal yang kemudiannya menampilkan wajah Islam Indonesia yang khas pula (Madjid, 1992: 35 ).

Para ahli sepakat bahwa Islam di kawasan kepulauan Nusantara sesungguhnya telah berkembang dengan pesat karena melalui proses akulturasi budaya lokal. Integrasi pemikiran Islam selalu disesuaikan dengan kekhasan budaya lokal. Wajar apabila dikatakan Islam Nusantara atau Islam Indonesia sebagai sesuatu yang unik; memiliki karakter yang khas; berbeda dengan Islam di kawasan lain, karena perbedaan sejarah dan perbedaan latar belakang geografis dan latar belakang budaya yang dipijaknya.

\section{Metode Penelitian}

Penelitian ini menggunakan pendekatan antropologis keagamaan sebagai upaya untuk memahami makna mendalam dari objek penelitian. Pendekatan antropologis adalah pendekatan kebudayaan, artinya agama dipandang sebagai bagian dari kebudayaan, baik wujud ide atau gagasan yang dianggap sebagai sistem norma maupun dan nilai yang dimiliki oleh anggota masyarakat, yang 
mengikat seluruh anggota masyarakat (Kahmad, 2000: 53).

Dalam konteks di atas, pendekatan antropologis atau kebudayaan dimaksud difungsikan dalam dua hal. Pertama, sebagai alat metodologi untuk memahami corak keagamaan masyarakat Banjar melalui tradisi Baayun Anak atau Baayun Maulid. Kedua, untuk menumbuhkan sikap toleran pemeluk agama (masyarakat Islam Banjar) terhadap perbedaan-perbedaan lokal yang terjadi karena suatu keyakinan agama yang damai kerap bisa berbeda dalam aspek-aspek lokalnya.

Lokasi penelitian dilaksanakan di Desa Banua Halat kecamatan Tapin Utara Kabupaten Tapin Rantau (Kalimantan Selatan) sebagai pusat dan asal muasal dilaksanakannya tradisi Baayun Anak atau Baayun Maulid.

Analisis dalam penelitian ini menggunakan pendekatan fenomenologi atau kualitatif yang bersifat deskriptif. Pendekatan kualitatif digunakan untuk memahami dan mendeskripsikan berbagai prilaku, sistem, dan makna yang terkandung dalam tradisi Baayun Anak dan segala faktor yang berhubungan dengan tradisi tersebut.

\section{Asal-usul Tradisi Baayun Anak-Baayun Maulid}

Tradisi Baayun Anak atau Baayun Maulid mulai populer dalam masyarakat Banjar. Dilaksanakan secara seremonial (paling tidak oleh masyarakat di Banua Halat) dan menyebar secara luas ke berbagai daerah di Kalimantan Selatan sejak tahun 1990-an. Sebagaimana penuturan H. Darmawi Abbas (salah seorang penduduk sepuh dan penyumbang tiang utama-soko guru masjid keramat Banua Halat), tradisi Baayun Maulid sudah dikenal oleh masyarakat Banua Halat sejak lama seiring dengan masuk dan tersebarnya Islam ke wilayah ini dan sekitarnya. Pada tahun 1900-an, tradisi ini telah diselenggarakan oleh masyarakat setiap kali datang bulan Rabiul Awal.

Menurut tutur lisan masyarakat Desa Banua Halat yang mengetahui secara langsung sejarah dan riwayat tradisi Baayun Maulid diketahui ada tiga hal penting yang menjadi latar belakang asal mula dilaksanakannya tradisi ini.

\section{a. Upacara Aruh Ganal}

Berdasarkan catatan sejarah yang ada, Islam diterima dan dinyatakan sebagai agama resmi kerajaan oleh pendiri kerajaan Islam Banjar, Sultan Suriansyah, pada tanggal 24 september 1526. Maka sejak itulah Islam berkembang cepat ke seluruh daerah di Kalimantan Selatan, terutama daerah-daerah aliran pinggir sungai (DAS) sebagai jalur utama transformasi dan perdagangan ketika itu, 
termasuk ke Banua Halat.

Jalur masuknya Islam ke Banua Halat adalah melalui jalur lalu lintas sungai dari Banjarmasin ke Marabahan, Margasari, terus ke Muara Muning hingga Muara Tabirai sampai ke Banua Gadang; kemudian dari Banua Gadang dengan melewati Sungai Tapin sampailah ke kampung Banua Halat. Diperkirakan Islam sudah masuk ke daerah ini sekitar abad ke-16.

Sebelum Islam masuk, orang-orang Dayak Kaharingan yang berdiam di kampung Banua Halat biasanya melaksanakan upacara aruh ganal. Aruh artinya kenduri atau selamatan dan ganal artinya besar; aruh ganal bermakna kenduri besar. Upacara ini dilaksanakan secara meriah dan besar-besaran ketika pahumaan (huma, ladang, tugalan atau sawah kering di daerah perbukitan) menghasilkan banyak padi, sebagai ungkapan rasa syukur atas karunia yang diberikan Tuhan. Kegiatan utama dalam upacara aruh ganal yang bisa dilaksanakan selama sepekan ini adalah pembacaan mantra dari para balian disertai dengan maayun atau Baayun Anak. Anakanak yang masih kecil diayun dalam ayunan yang secara khusus dibuat dan disediakan serta dihias dengan berbagai perlengkapan yang seakan ingin mengajarkan kepada anak-anak untuk bersyukur atas karunia yang didapat. Selain itu agar anak-anak yang diayun tersebut mendapat keselamatan dan keberkatan dari 'penguasa alam gaib' setelah melalui proses pembacaan mantra-mantra tertentu.

Setelah Islam masuk dan berkembang, upacara tersebut tetap dilaksanakan dengan format yang sama, tetapi dengan substansi yang berbeda. Pada mulanya upacara ini diisi dengan bacaan-bacaan balian (tetuha/tokoh agama orang Dayak), mantra-mantra, doa dan persembahan-persembahan yang ditujukan kepada para dewa serta para leluhur ataupun roh nenek moyang orang Dayak Banua Halat dan dilaksanakan di balai. Kini bacaan tersebut digantikan dengan pembacaan syair-syair maulid Nabi yang berisi sejarah, perjuangan, dan pujian terhadap Nabi Muhammad SAW. Tempat pelaksanaannya pun kemudian dipusatkan di Masjid al Mukarramah yang merupakan peninggalan dan didirikan oleh intingan atau datu ujung selaku tokoh Islam yang dihormati oleh orang-orang Banua Halat.

Pelaksanaannya dirangkaikan dengan peringatan maulid Nabi Muhammad SAW tanggal 12 Rabiul Awal. Acara diisi dengan pembacaan syair-syair maulid, pembacaan al Quran, doa, ceramah agama, sekaligus pula diikutsertakannya atau diayunnya anak-anak yang masih kecil maka akhirnya tradisi ini populer dan dinamakan upacara Baayun Maulid. 
Tradisi Baayun Maulid ini sendiri bagi sejarawan dianggap sebagai penanda penting konversi atau masuk Islamnya orang-orang Dayak Banua Halat. Diawali dengan masuk islamnya Intingan (palui anum), sedangkan kakaknya yang bernama Dayuhan (palui tuha) tetap beragama Kaharingan. Dayuhan kemudian memisahkan diri dengan adiknya, namun sebelumnya mereka sempat membuat kesepakatan. Batas wilayah yang disepakati adalah Banua Halat bagian atas atau pedalaman menjadi wilayah dayuhan dan bagian luar adalah wilayah intingan. Meskipun mereka telah berbeda keyakinan, namun mereka tetap sepakat untuk terus menjaga tali persaudaraan dan saling hormat-menghormati, sehingga jika keturunan dayuhan bertemu dengan keturunan intingan maka mereka akan menyapa dengan ucapan dangsanak. Dalam Bahasa Banjar dangsanak artinya saudara kandung. Badingsanak berarti bersaudara karena itu, apabila kata sapaan ini ditujukan kepada seseorang maka maksudnya orang tersebut dianggap sebagai saudara kandung dari orang yang menyapa (Hapip, 2008: 30).

Selanjutnya untuk menjaga silaturahmi dan persaudaraan dengan kakaknya dan tetap melestarikan tradisi nenek moyang maka intingan dan orang-orang Dayak Banua Halat yang telah memeluk agama Islam tetap melaksanakan upacara Baayun Anak yang kemudian berubah nama dan disebut dengan tradisi Baayun Maulid.

b. Penghormatan terhadap Datu Ujung

Berdasarkan folklore (cerita rakyat) yang berkembang, tradisi Baayun Maulid juga dilatarbelakangi oleh anggapan masyarakat Banua Halat sebagai salah satu bentuk silaturahmi, penghormatan atau persahabatan dengan makhluk gaib, yaitu datu ujung. Datu ujung merupakan tokoh Islam dan nenek moyang orang Dayak yang pertama kali memeluk agama Islam. Sejarah hidup datu ujung sendiri terkait dengan riwayat pendirian masjid keramat Al Mukarramah.

Mitologi orang-orang Dayak Bukit di pegunungan Meratus daerah Tapin menyebutkan bahwa masjid tersebut didirikan oleh nenek moyang mereka yang bernama Intingan (palui anum). Menurut mitos tersebut, dahulu kala ada dua orang bersaudara kakak beradik, yang tua namanya Dayuhan (palui tuha) dan yang adik nama Intingan (palui Anum). Setelah Intingan memeluk agama Islam, ia kemudian dipanggil oleh pengikutnya dengan nama datu ujung, sedangkan Dayuhan tetap mempertahankan kepercayaan lamanya, yakni animisme. Dayuhan dengan sikapnya yang tidak setuju dengan adiknya yang telah beragama Islam kemudian memisahkan diri 
dan masuk ke pedalaman daerah pergunungan yang sulit dijangkau oleh manusia lainnya. Datu ujung inilah yang menurut tradisi lisan masyarakat Banua Halat dianggap sebagai penduduk asal dan yang mempelopori pendirian masjid keramat Al Mukarramah Desa Banua Halat.

Menurut Gazali Usman, kekeramatan Masjid al Mukarramah Desa Banua Halat tergambar dari perlakuan masyarakat yang ditandai dengan adanya (Usman, 2010: 15):

1. sewaktu-waktu masyarakat setempat atau tutus (keturunan atau penduduk asal) Banua Halat dari daerah lain datang dan mengadakan selamatan di dalam masjid tersebut untuk meminta berkah dan keselamatan.

2. adanya orang-orang yang menaruh atau menempatkan botol-botol berisi air putih ada bagian tertentu masjid, terutama pada tangga mimbar selama beberapa hari agar air tersebut memiliki berkah sehingga dapat menyembuhkan penyakit atau melancarkan usaha dan terpenuhinya (kabul) hajat.

3. salah satu tiang masjid (tiang soko guru) yang terletak di sudut barat merupakan tiang peninggalan datu ujung. Tiang ini dianggap luar biasa karena dibuat oleh datu ujung dari tatalan atau potongan kayu yang diikat dan dikumpulkan (seperti halnya cerita Sunan Kalijaga ketika membuat tiang salah satu Masjid Demak dari tatalan kayu). Tiang ini selalu dilumuri dengan minyak kental (minyak kelapa) hingga berwarna hitam. Minyak kental pada tiang tersebut sering dioleskan pada anak-anak bahkan orang dewasa yang sakit dengan harapan supaya lekas sembuh.

4. di Masjid al Mukarramah Banua Halat ini setiap tanggal 12 Rabiul awal selalu dilaksanakan upacara besar, yakni upacara Baayun Maulid, sebuah upacara peringatan maulid Nabi sekaligus maayun anak.

Masyarakat juga meyakini juga bahwa datu ujung bukan hanya sebagai penunggu masjid, tetapi juga menjaga zuriat, tutus atau keturunan orangorang Desa Banua Halat dari segala musibah. Itulah sebabnya, di mana pun orang-orang berasal dari Desa Banua Halat berada, mereka tetap merasa memiliki keterikatan dengan datu ujung dan memiliki keharusan untuk selalu mengikutsertakan setiap anggota keluarga mereka dalam prosesi Baayun Maulid. 


\section{c. Kepercayaan Warisan Nenek Moyang}

Orang-orang Banua Halat yang semula memiliki keyakinan animisme mempercayai bahwa setiap anak yang dilahirkan ke dunia tidaklah sendiri, akan tetapi mereka disertai pula oleh empat saudara gaibnya. Keempat saudaranya yang gaib tersebut adalah tambuniah, tubaniah, uriah, dan kamariah. Mereka menjadi teman sepermainan anak yang baru lahir. Kemudian, agar keempatnya tidak mengganggu yang berakibat pada sakitnya anak maka oleh orangtuanya ketika anak berumur 40 hari ia harus ditapung tawari, sekaligus diayun. Semua prosesi itu biasanya dilakukan oleh seorang bidan yang telah membantu proses kelahiran anak disertai dengan segala macam bacaan tertentu, seperti mamangan atau mantra yang diucapkan bidan tersebut ketika manapung tawari dan maayun anak.

Masyarakat Banjar sendiri kemudian menamakan acara ini dengan sebutan bapalas bidan. Seorang bayi yang baru lahir dinyatakan sebagai anak bidan sampai dilaksanakannya upacara bapalas bidan, yakni suatu upacara pemberkatan yang dilakukan oleh bidan terhadap si bayi dan ibunya. Maksud pelaksanaannya sebagai balas jasa terhadap bidan dan sebagai penebus atas darah yang telah tumpah ketika melahirkan. Harapan diadakannya bapalas bidan ini agar tidak terjadi pertumpahan darah yang diakibatkan oleh kecelakaan atau perkelahian di lingkungan tetangga maupun atas keluarga sendiri karena darah yang tumpah telah ditebus oleh si anak pada waktu upacara bapalas bidan tersebut. Pada upacara bapalas bidan ini si anak dibuatkan ayunan yang diberi hiasan yang menarik, seperti udang-udangan, belalang, dan urung ketupat dengan berbagai bentuk, serta digantungkan bermacam-macam kue tradisional Banjar, seperti сucur, cincin, apam, pisang, dan lain-lain. Kepada bidan yang telah berjasa menolong persalinan itu diberikan hadiah (piduduk); segantang beras, jarum, benang, seekor ayam (untuk anak laki-laki ayam jantan dan untuk anak perempuan diberikan ayam betina), sebiji kelapa, rempah-rempah dan bahan untuk menginang seperti sirih, kapur, buah pinang, gambir, tembakau, dan uang ala kadarnya (Daud, 1997: 240).

Setelah Islam masuk ke Banua Halat dan sebagian besar penduduknya telah memeluk agama Islam, maka kepercayaan-kepercayaan yang berbau animisme tersebut sedikit demi sedikit dihilangkan dan diganti dengan keyakinan terhadap Islam. Tradisi Baayun Anak yang semula merupakan tradisi yang berbau animisme kemudian diislamisasikan melalui proses akulturasi dan transformasi. 
Proses akulturasi tersebut telah memberikan pemahaman baru dan makna penting bagi masyarakat Banua Halat. Sejak kecil anak-anak telah dikenalkan dengan masjid, sehingga diharapkan sepanjang hidupnya selalu ingat dan menjadikan masjid sebagai pusat peribadatan. Kemudian, sejak dini anak juga sudah dikenalkan dan diikutsertakan dengan perayaan maulid Nabi sebagai ungkapan rasa syukur atas kegembiraan atan kelahiran Nabi Muhammad SAW yang telah membawa petunjuk bagi seluruh umat manusia, dengan harapan anak akan selalu ajaran yang disampaikan oleh beliau dan menjadikan beliau sebagai ikutan, contoh ataupun suri teladan yang paling baik dan utama.

\section{Prosesi Baayun Anak-Baayun Maulid}

Prosesi pelaksanaan dari kegiatan Baayun Maulid dapat dilihat dari: a. waktu dan tempat kegiatan; b. alat dan perlengkapan kegiatan; dan c. makna simbolik perlengkapan.

Waktu dan tempat kegiatan. Sebagai upacara yang dilaksanakan untuk mengungkapkan rasa syukur atas kelahiran Nabi Muhammad SAW, maka waktu pelaksanaan untuk upacara Baayun Maulid di Desa Banua Halat ini hanya dilaksanakan satu kali dalam setahun, yakni pada bulan maulid, bertepatan dengan tanggal kelahiran Nabi Muhammad SAW, yakni 12 Rabiul Awal. Apabila pada tanggal 12 Rabiul Awal tersebut jatuh pada hari Jumat, maka waktu pelaksanaannya bisa dimajukan pada hari Kamis atau diundur pada hari Sabtu, supaya tidak mengganggu pelaksanaan shalat Jumat.

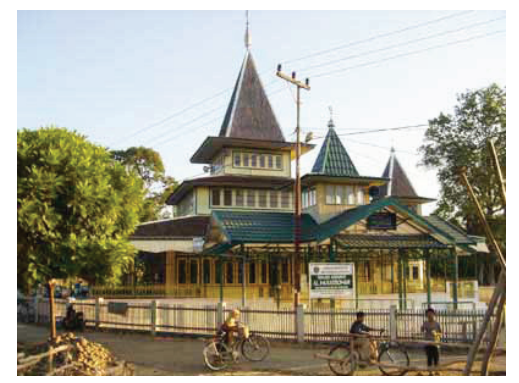

Gambar 1 : Masjid al Mukarramah di Desa Banua Halat Rantau

Tempat pelaksanaan upacara Baayun Maulid di Desa Banua Halat ini dipusatkan di Masjid al Mukarramah, yakni di halaman luar masjid. Hal ini bertujuan agar anak-anak yang menjadi peserta Baayun Maulid selalu dekat dan terikat dengan masjid sebagai pusat peribadatan dan peradaban umat 
Islam serta tidak melupakan ibadah shalat dan persatuan umat yang telah dilaksanakan di masjid. Selain itu, masjid juga dianggap sebagai tempat suci yang harus selalu dijaga kebersihannya, sehingga bermula dari sini diharapkan anak-anak yang mengikuti upacara Baayun Maulid memiliki dan selalu menjaga hatinya agar selalu suci dan bersih pula.

Alat dan perlengkapan kegiatan. Perlengkapan yang harus disediakan antara lain ayunan, hiasan atau kembang ayunan, wadai atau kue tradisional khas Banjar, piduduk, tangga manisan (tebu), dan lain-lain. Ayunan misalnya, biasanya terdiri dari tiga lembar kain panjang wanita (tapih bahalai); dua lembar terbuat dari kain sasirangan atau batik dan satu lembar kain kuning. Tapih bahalai tersebut kemudian diikat sisi kanan dan sisi kirinya dengan tali yang digantungkan pada sebatang pipa besi atau batang bambu) yang telah dibentangkan dalam beberapa baris (yang disesuaikan dengan jumlah peserta) di halaman masjid. Kemudian, ayunan tersebut juga dihiasi dengan anyaman terbuat dari janur (daun kelapa muda yang berwarna kuning) dinamakan janur kumbuh yang berbentuk macam-macam, seperti payung singgasana, patah kangkung, rantaian kembang sarai, pagar tigarun, tangga putri (maksudnya tangga Putri Junjung Buih), tangga pangeran (maksudnya tangga Pangeran Samudera atau Sultan Suriansyah), sapit udang, dan ular-ularan. Bagian tengahnya diikat dan dihiasi dengan kain selendang atau kerudung panjang yang berfungsi sebagai penutup.

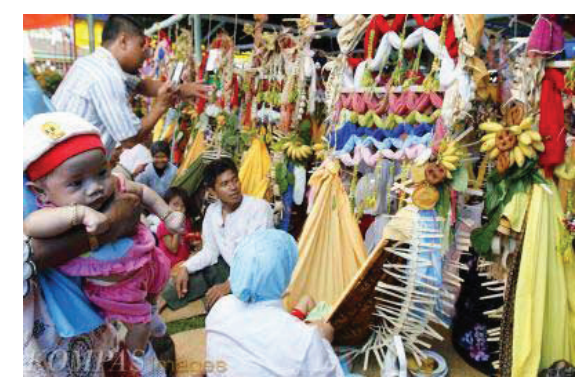

Gambar 2: Ayunan yang telah dihias akan digunakan dalam Baayun Maulid

Kue atau wadai tradisional masyarakat Banjar sebagai pengiring kegiatan terdiri dari 41 jenis. Adapun piduduk atau biasa pula disebut dengan sasarahan adalah sejumlah barang yang menjadi perlambang (simbol) dan tanda kasih dari peserta Baayun Maulid ini. Piduduk untuk peserta Baayun Maulid dimaksud antaranya beras, benang, jarum, gula merah, kelapa, beras kuning, uang logam, nasi ketan (lakatan), telur bebek-itik, minyak kental atau biasa oleh orang 
Banjar disebut dengan minyak baboreh, dan lain lain. Semua bahan piduduk ini diletakkan dalam baskom plastik kecil atau bakul.

Makna simbolik perlengkapan. Perlengkapan yang telah disediakan oleh setiap peserta kegiatan Baayun Maulid memiliki banyak makna dan nilai filosofis yang bisa menjadi pelajaran bagi masyarakat luas. Ayunan, melambangkan suatu tradisi khas kedaerahan (lokal) atau budaya khas dari kehidupan masyarakat (Dayak-Banjar); piduduk melambangkan berbagai hal yang berhubungan dengan kehidupan sehari-hari, seperti kecukupan bahan pangan, ikatan kekerabatan, lambing usaha atau etos bekerja, dan lain-lain.

Pada umumnya peserta Baayun Maulid ini terbagi dalam dua kelompok, yakni kelompok anak-anak (bayi) dan kelompok orang dewasa baik laki-laki maupun perempuan. Adapun yang dimaksud dengan pimpinan upacara adalah orang-orang yang memimpin pelaksanaan upacara Baayun Maulid, mereka adalah kelompok pembaca syair-syair maulid yang diketuai oleh salah satu di antara mereka dan kelompok itu sudah ditunjuk oleh ketua panitia.

Pelaksanaan: Pada bagian ini, tradisi Baayun Maulid dilakukan melalui dua tahapan penting, yakni tahap persiapan dan tahap pelaksanaan.

Tahap Persiapan. Persiapan untuk melaksanakan upacara Baayun Maulid secara umum dilakukan sampai sesaat menjelang upacara dilaksanakan. Adapun persiapan yang harus dilakukan antara lain adalah menentukan dan mempersiapkan tempat pelaksanaan upacara, menetapkan kelompokkelompok pembaca syair-syair maulid, penyerahan piduduk kepada tokoh agama, pembuatan ayunan beserta hiasannya, membuat kue dan memasak makanan untuk dihidangkan, dan sebagainya.

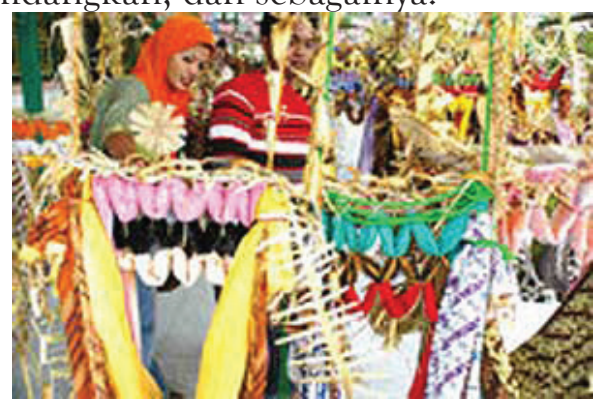

Gambar 3: Para peserta sedang sibuk menghias ayunan

Tahap Pelaksanaan. Pelaksanaan kegiatan Baayun Maulid ditandai oleh dua kegiatan penting, yaitu: pembacaan syair-syair maulid yang berisi pujipujian kepada Nabi Muhammad SAW dan kegiatan mengayun anak. 


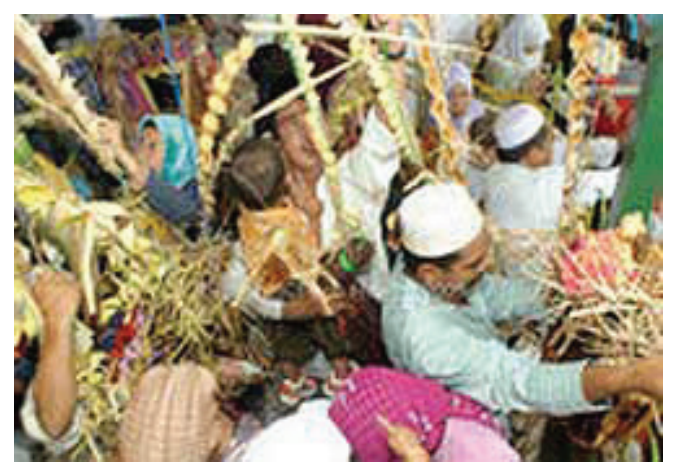

Gambar 4: Prosesi mengayun anak

Kegiatan mengayun anak bersamaan dengan pembacaan syair-syair maulid, terutama pada saat pembacaan asyraqal sampai berakhir. Selanjutnya diteruskan dengan ceramah atau uraian tentang Maulid Nabi Muhammad SAW oleh tokoh agama yang terkemuka. Sebagai penutup upacara diakhiri dengan pembacaan doa dan atau ceramah, nasihat, atau tausiyah keagamaan yang juga dibacakan oleh salah seorang tokoh ulama yang ditunjuk.

Maksud dan tujuan Baayun Anak selain didasari oleh motif-motif tertentu dalam mereka yang mengikuti tradisi ini juga memiliki tujuan-tujuan khusus, di antara tujuan-tujuan dimaksud adalah:

1. bagi orang tua yang mengikutkan anaknya dalam pelaksanaan baayun maulid ini, ia berharap agar anak (bayi) yang diikutkan dalam Baayun Maulid tersebut, kelak jika sudah dewasa akan meneladani perilaku dan akhlak Nabi Muhammad SAW, dimudahkan hidupnya, dan selalu melaksanakan ajaran agama dengan baik.

2. Baayun Maulid adalah bagian orang-orang yang berasal dari Desa Banua Halat yang tidak boleh ditinggalkan, jadi harus dilaksanakan di manapun mereka berada, sebab jika tidak dilaksanakan maka seorang anak (bayi) bisa sakit-sakitan.

3. dalam rangka untuk melaksanakan nazar, misalnya nazar apabila sembuh dari sakit (penyakit) atau terpenuhi apa yang diinginkan maka akan melaksanakan Baayun Maulid.

4. mohon perlindungan terhadap keturunan karena adanya rasa khawatir apabila tidak melaksanakan Baayun Maulid tersebut mereka akan mendapat musibah nanti.

5. untuk mempertahankan dan melestarikan data atau tradisi dari 
nenek moyang agar tidak hilang begitu saja seiring dengan berlalunya waktu.

6. dalam rangka merayakan atau memeriahkan hari lahirnya Nabi Muhammad SAW dengan harapan agar masyarakat (lebih-lebih lagi mereka yang mengikuti atau menjadi peserta Baayun Maulid) dapat meneladani perilaku Nabi Muhammad SAW.

7. menciptakan rasa kekeluargaan dan silaturrahmi, karena dengan melaksanakan upacara Baayun Maulid, maka seluruh keluarga dan masyarakat dapat berkumpul serta bersilaturrahmi untuk memeriahkannya.

8. khusus bagi peserta Baayun Maulid dewasa, ada juga yang melakukan Baayun Maulid untuk mempermudah mereka dalam mencapai tujuan yang belum didapat, misalnya mencari pekerjaan, jodoh, atau memperlancar karir.

Pada kegiatan Baayun Maulid di Desa Banua Halat ada beberapa pantangan atau larangan-larangan yang harus dipatuhi oleh peserta upacara. Larangan tersebut bertujuan untuk lebih tertibnya pelaksanaan upacara dan untuk menghilangkan hal-hal yang memang dilarang dalam agama. Adapun larangan-larangan tersebut antara lain adalah:

1. pada saat baayun, peserta tidak boleh diwakilkan atau diganti oleh salah satu keluarga atau orang lain.

2. ayunan (tapih bahalai) yang digunakan untuk baayun harus tiga lapis, tidak boleh bermotifkan hewan, misalnya naga atau burung elang dan makhluk hidup lainnya. Islam melarang untuk melukis benda-benda bernyawa, sehingga motif hewan diganti dengan motif tumbuhan, bunga, atau gambar-gambar tertentu yang bukan makhluk hidup.

3. begitu pula halnya dengan model janur yang digunakan dan dibuat sebagai hiasan tidak boleh berupa benda hidup/menyerupai hewan, misalnya burung.

4. pada waktu berlangsungnya upacara, bagi perempuan baik peserta maupun mereka yang menghadiri tidak diperbolehkan masuk ke dalam masjid, agar masjid tetap bersih, tidak sesak, dan sebagainya.

5. para tamu atau undangan tidak diperkenankan mengganggu ayunan atau mengambil salah satu dari hiasan yang telah dipasang pada ayunan apalagi memperebutkannya, karena ayunan dan segala yang ada di dalamnya merupakan hak dari peserta. Oleh itu, makanan 
atau hiasan ayunan boleh diambil apabila telah mendapatkan izin atau memang diberikan oleh peserta yang baayun.

\section{Pembahasan}

Latar belakang atau sejarah mulanya dilaksanakan upacara Baayun Maulid di Desa Banua Halat kiri pada prinsipnya tidak lepas dari prosesi maayun anak dalam acara aruh ganal yang biasa dilaksanakan oleh orang-orang Dayak sebelum mereka memeluk agama Islam. Setelah mereka memeluk agama Islam, maka acara ini kemudian mengalami proses akulturasi dan islamisasi oleh para juru dakwah yang menyampaikan Islam ke daerah ini.

Walaupun sudah mengalami proses akulturasi dan islamisasi, namun konsep awal dari kegiatan ini terkadang masih diyakini oleh sebagian masyarakat yang ada di Desa Banua Halat. Misalnya paham terhadap empat saudara kembar yang selalu menyertai setiap anak yang baru lahir, sehingga agar tidak mengganggu, seorang anak harus melalui ritual baayun.

Adapun alasan diadakannya kegiatan tersebut disertai dengan Baayun Anak atau Baayun Maulid, karena menurut keyakinan masyarakat mempunyai hubungan dengan kelahiran Nabi Muhammad SAW, yaitu dengan mendengarkan syair-syair dalam peringatan tersebut, sianak diharapkan nantinya dapat meneladani kepribadian, akhlak, dan perilaku Nabi Muhammad SAW.

Nilai utama yang hendak ditanamkan oleh para ulama dalam upacara Baayun Anak dan mengisinya dengan pembacaan syair-syair maulid di Desa Banua Halat tersebut tidak lain sebagai bagian dari strategi dakwah kultural, yakni bentuk dakwah yang dilakukan melalui pendekatan aspek penjelasan dan tindakan yang bersifat sosiokultural dan keagamaan, jadi bukan dengan pendekatan politik, salah satunya adalah dengan mengunakan medium seni budaya (Azra, 2003: 2). Atau dimaknai sebagai suatu upaya menyampaikan ajaran Islam dengan mengakomodir budaya lokal serta lebih menyatu dengan lingkungan hidup masyarakat setempat (Umar, 2003: 3). Karena pada akhirnya dakwah kultural menghendaki adanya kecerdikan dalam memahami kondisi masyarakat dan kemudian mengemasnya sesuai dengan pesan-pesan dakwah Islam (Mulkhan, 2003: 2).

Sehingga dengan model dakwah itu mereka tetap menjaga dan melestarikan sebuah tradisi dengan prinsip "setiap budaya yang tidak merusak akidah dapat dibiarkan hidup”, sekaligus mewariskan dan menjaga nilai-nilai dasar kecintaan umat kepada Nabi Muhammad SAW, untuk dijadikan panutan dan teladan dalam kehidupan berkeluarga, bermasyarakat, dan berpemerintahan. 
Berdasarkan kenyataan di atas, Baayun Anak adalah salah satu simbol pertemuan antara tradisi dan ajaran agama. Mengayun anak, jelas sebuah tradisi lokal yang dilakukan oleh masyarakat Banjar dan Dayak secara turuntemurun dari dulu hingga sekarang untuk menidurkan anak-anak. Sedangkan memberi nama anak, berdoa, membaca shalawat, ataupun membaca al Quran, dan silaturrahmi merupakan anjuran dan perintah agama. Kedua ritus, secara harmoni telah bersatu dalam kegiatan Baayun Anak, yang bahkan secara khusus dilaksanakan pada bulan Rabiul Awal sebagai peringatan sekaligus penghormatan atas kelahiran Nabi Muhammad SAW. Inilah dialetika agama dan budaya, budaya berjalan seiring dengan agama dan agama datang menuntun budaya.

Ditinjau dari segi filosofi atau nilai-nilai yang terkandung dalam tradisi ini, maka didapat beberapa hal yang menjadi nilai atau muatan-muatan dakwah yang terkandung dalam upacara tersebut (realitas ini merupakan hasil dari integrasi atau akulturasi nilai-nilai kearifan lokal dengan Islam) antara lain adalah: Pertama, ajakan untuk meneladani perilaku, akhlak, dan perjuangan Nabi Muhammad SAW, kemasyarakatan, maupun dalam kehidupan berkeluarga.

Kedua, ajakan untuk menjadikan masjid sebagai pusat kehidupan dan peribadatan, karena dari masjid bermuara dan hendak di masjid pula berakhir. Ketiga, ajakan untuk menjaga silaturrahmi. Karena dari perayaan Baayun Maulid akan terjadi hubungan, interaksi dan komunikasi antara sesama umat Islam, baik mereka yang berasal dari Desa Banua Halat maupun berasal dari luar. Keempat, ajakan untuk menjaga persatuan, musyawarah, dan gotong-royong. Persatuan antar sesama umat Islam, terlebih dalam memperingati dan memuliakan Nabi Muhammad SAW melalui peringatan hari kelahirannya.

Itulah sebabnya setiap kali upacara Baayun Maulid dilaksanakan, panitia pelaksana sudah memberikan beberapa informasi penting berkenaan dengan pantangan-pantangan yang harus dijauhi (pamali) oleh peserta Baayun Maulid serta berbagai hal yang berhubungan dengan makna perlengkapan yang harus dipenuhi oleh setiap peserta. Misalnya, ketidakbolehan menggunakan perlengkapan yang bergambar hewan hidup, jumlah perlengkapan yang harus dalamm hitungan ganjil, dan berbagai simbol lainnya yang memiliki makna maupun filosofis yang berguna untuk kehidupan anak nanti.

Tradisi Baayun Maulid ini tidak hanya mengandung nilai-nilai religius semata, tetapi seiring dengan perkembangan nilai-nilai agama yang terkandung di dalamnya telah bertransformasi dan berpadu dengan nilai-nilai yang lainnya, 
seperti nilai sosial, budaya, dan ekonomi.

Pertama, nilai sosial. Nilai sosial dari pelaksanaan upacara Baayun Maulid dapat dilihat dari para pesertanya yang berasal dari segenap lapisan masyarakat dengan latar belakang ekonomi, sosial, politik dan umur yang berbeda-beda. Ketika modernitas telah berhasil membentuk manusia-manusia modern yang individualis, maka pelaksanaan upacara ini merupakan ajang silaturahim untuk membangun nilai-nilai kemanusiaan yang humanis; saling menghargai, menghormati, dan tidak takut untuk berbagai.

Kedua, nilai budaya. Mengayun anak pada saat upacara Baayun Maulid merupakan salah satu bentuk ekspresi dari nilai-nilai lokal yang hidup dan berkembang dalam masyarakat. Dengan diayun, seorang anak akan mendapatkan ketenangan dan ketentraman karena berada dalam perlindungan dan limpahan kasih orangtuanya. Dengan cara ini nilai-nilai lokal diwariskan sehingga dimungkinkan untuk terus lestari.

Ketiga, nilai ekonomi. Seiring perkembangan zaman, pelaksanaan upacara Baayun Maulid tidak sekadar ritual, tetapi juga sebuah festival budaya yang mempunyai potensi untuk meningkatkan kemakmuran masyarakat. Dengan dikembangkan potensi ekonominya, maka pelaksanaan upacara Baayun Maulid tidak hanya akan memberikan kebahagiaan secara rohani kepada yang melaksanakan, tetapi juga akan meningkatkan kesejahteraan masyarakat.

\section{Simpulan}

Kegiatan Baayun Maulid pada prinsipnya adalah upacara keagamaan yang merupakan tradisi lokal yang bernafaskan atau mengandung unsur-unsur dakwah Islam. Pelaksanaannya dilakukan bertepatan dengan peringatan atau perayaan kelahiran Maulid Nabi tanggal 12 Rabiul Awal yang diperingati di Masjid al Mukarramah Banua Halat. Peserta yang mengikuti upacara ini terdiri dari anak-anak dan orang dewasa. Nilai-nilai dakwah Islam yang terkandung dalam Baayun Maulid ini dapat dilihat dari berbagai aspek, misalnya dilihat dari tempat pelaksanaannya yang dipusatkan di masjid yang tujuannya untuk mendekatkan dan menanamkan kecintaan kepada masjid. Baayun Maulid atau Baayun Anak adalah proses budaya yang menjadi salah satu simbol kearifan dakwah ulama Banjar dalam mendialogkan makna hakiki ajaran agama dengan budaya masyarakat Banjar. Maulid adalah simbol agama dan menjadi salah satu manifestasi untuk menanamkan, memupuk, dan menambah kecintaan sekaligus pembumian sosok manusia pilihan, manusia teladan, Nabi pembawa Islam, untuk mengikuti ajaran dan petuahnya. Sedangkan Baayun Anak 
penerjemahan dari manifestasi tersebut, karena dalam Baayun Anak terangkum deskripsi biografi Nabi Muhammad SAW sekaligus doa, upaya, dan harapan untuk meneladaninya.

Agar supaya keyakinan dan pemahaman masyarakat tidak bercampur dengan pengaruh animisme atau dinamisme yang masih ada dalam kegiatan Baayun Maulid, maka sudah menjadi tugas juru dakwah, tokoh agama, tuan guru (ulama), dan tokoh masyarakat untuk meluruskan serta secara berkesinambungan menjaga nilai-nilai keIslamannya, dan memberi arahan, bimbingan, serta petunjuk kepada masyarakat tentang hal-hal yang tidak sesuai dengan ajaran Islam, agar mereka menjauhinya.

\section{Daftar Pustaka}

Azra, Azyumardi. 2003. Islam Nusantara: Jaringan Global dan Lokal. Bandung: Mizan.

Daud, Alfani. 1997. Islam dan Masyarakat Banjar: Deskripsi dan Analisis Kebudayaan Banjar. Jakarta: PT. Raja Grafindo Persada.

Hadi, Sumandiyo. 2006. Seni dalam Ritual Agama. Yogyakarta: Pustaka.

Hapip, Abdul Djebar. 2008. Kamus Banjar Indonesia. Banjarmasin: CV. Rahmat Hafiz Mubaraq.

Hidayat, Komaruddin. 1992. Agama-agama di Dunia: Masalah Interrelasi, Kontinuitas, dan Perkembangan. Jakarta: Yayasan Paramadina.

Kahmad, Dadang. 2000. Metode Penelitian Agama. Bandung: Pustaka Setia.

Keesing, Roger. 1992. Antropologi Budaya. Jakarta: Erlangga.

Koentjaraningrat. 2002. Pengantar Ilmu Antropologi. Jakarta: PT. Rineka Cipta.

Kuntowijoyo. 2001. Muslim Tanpa Masjid: Essai-essai Agama, Budaya, dan Politik dalam Bingkai Strukturalisme Transendental. Bandung: Mizan.

Madjid, Nurcholish. 1992. Islam, Doktrin, dan Peradaban. Jakarta: Yayasan Paramdina.

Mulkhan, Abdul Munir. 2003. Dakwah Kultural: Citra Organisasi Pembasmi TBC di Masyarakat Transisi. Tabloid Republika Dialog Jumat, edisi 27 Juni 2003: 3 (1-2). 
Paisun. 2010. Dinamika Islam Kultural: Studi atas Dialektika Islam dan Budaya Lokal Madura. Prosiding Annual Conference on Islamic Studies ke10. Banjarmasin: IAIN Antasari.

Sartini. 2004. Menggali Kearifan Lokal Nusantara: Sebuah Kajian Filsafati. Jurnal Filsafat. Jilid 37, Nomor 2: 111-120.

Tim Penyusun. 1999. Kamus Besar Bahasa Indonesia. Jakarta: Balai Pustaka.

Tim Penyusun. 2008. Kamus Bahasa Indonesia. Jakarta: Pusat Bahasa Departemen Pendidikan Nasional.

Umar, Husien. 2003. Dakwah Kultural Bagian dari Strategi Dakwah Islam. Tabloid Republika Dialog Jumat, edisi 27 Juni 2003: 5 (1-3).

Usman, A Gazali. 2000. Tradisi Baayun Mulud 12 Rabiul Awal di Mesjid Keramat Banua Halat Rantau Kabupaten Tapin. Banjarmasin: Pemerintah Daerah Tingkat II Tapin. 